\title{
THE USE OF WASTE SIEVING TOOLS TO SUPPORT THE WASTE COMPOSTING PROCESS IN THE CAMPUS 7 OF HEALTH POLYTECHNIC OF MINISTRY OF HEALTH SEMARANG
}

\author{
Suparmin ${ }^{1)}$, Sugeng Abdullah ${ }^{2)}$, Wahyu Putriyantari ${ }^{3)}$ \\ 1, 2, 3)Environmental Health Department, Health Polytechnic of Ministry Health Semarang, \\ Indonesia \\ Corresponndence email : pakparmin@yahoo.com
}

\begin{abstract}
Introduction: Campus 7 Health Polytechnic of the Ministry of Health Semarang, is an educational institution that is integrated with a canteen, housing for lecturers and has an open area of 2.3 ha where organic waste is generated on average $4 \mathrm{~m} 3$ / week and an average of 0.85 inorganic waste $\mathrm{m} 3$ / week predominantly plastic. Campus 7 as an educational institution in which there is a Department of Environmental Health and has qualified human resources (HR) in the field of waste processing has pioneered a composter pilot unit with the run way method which is arranged in 10 basins. Based on the description above, the formulation of the problem in this study is to determine the effectiveness of the compost sieve engineering tool in supporting the waste processing process. Methods: Pre-experiment with Post Test Only Design research design. With the design of tools for comparing the results before and after using the tools used. This research was conducted at a waste processing place (composter) at Campus 7 Poltekkes Kemenkes Semarang. The population in this study is all of the waste generation from campus 7 residents. The sample of this research is the waste contained in the final tub (10th) of compost processing, with a volume of 0.5-1 $\mathrm{m} 3$ / week. The data analysis used in this research is table analysis and the average value calculated from the results of sieving the waste. Result and discussion: Research and Development is a research method that uses to obtain or develop products and test the effectiveness of these products. The volume of waste from the end of final processing (tub 10) is around 531.2 liters $(238.5 \mathrm{~kg})$. The amount of plastic waste that was sorted manually was $176 \mathrm{lt}(43.5 \mathrm{~kg})$, so the amount of waste that needed to be sieved was around 355.2 liters $(195 \mathrm{~kg})$. Comparison of the results of manual sifting of waste takes about 75 minutes with 3 workers, it is obtained that the waste is separated into 3 parts as follows : Plastic waste by the size $>5 \mathrm{~cm}(24.5 \mathrm{~kg})$, large compost waste by the size $>5 \mathrm{~cm} \mathrm{~s}$. D $>1 \mathrm{~cm}$ by $94.4 \mathrm{lt}(53 \mathrm{~kg})$ and small compost by the size $<1 \mathrm{~cm}$ by $188.8 \mathrm{lt}(117.5 \mathrm{~kg})$. Sifting capability is approximately $4,74 \mathrm{lt} /$ minute $(2.6 \mathrm{~kg} /$ minute $)$. Machine-sifting takes about 23 minutes with 2 workers, collected waste into 4 parts as follows: plastic trash by the size $>5 \mathrm{~cm}$ as much as $73.6 \mathrm{lt}(33.05 \mathrm{~kg})$, large composite waste and plastic D > 2 cm as much as $61 \%$ lt $(27.39 \mathrm{~kg})$, huge compost waste D $>1 \mathrm{~cm}$ as much as $35 \mathrm{lt}(15.715 \mathrm{~kg})$ and a small compost measure $<1 \mathrm{~cm}$ as much as $185.6 \mathrm{lt}(83.33 \mathrm{~kg})$. The capability of sifting about $1544 \mathrm{lt} /$ minute $(8.5 \mathrm{~kg} /$ minute $)$.
\end{abstract}

Conclusion: The tool needeed to accelerate the disposal of waste into sieving machine.

Keywords: Engineering Tools Sanitation, Waste Processing, Composting, Waste Siever

\section{Introduction}

Waste is an item that is produced from the activities of humans and other living things that are no longer used. Waste will become an environmental problem if it is not managed properly. Various types of waste generated from human activities in the form of organic and inorganic waste. Each of these types of waste needs proper management so as not to cause environmental problems (Marwati, 2013).

Waste is a source of disease, either directly or indirectly. Directly, waste is a place for various parasites, bacteria and pathogens to grow; while indirectly waste is a nest for various vectors (disease carriers) such as mice, cockroaches, flies and mosquitoes. Rotting waste, as well as cans, bottles, plastics, is a hotbed of pathogens and disease vectors. Various diseases that can arise due to poorly managed waste are diarrhea, dysentery, worms, malaria, elephantiasis and dengue fever. These diseases are a threat to humans, which can cause death. (Imran SL Tobing, 2005). 
Nowdays, waste is a national issue that has not had an optimum solution yet tends to be a constant problem every year. As a result of the lack of integrated policy or program management and lack of support and participation in both the business and the public.

During its development, it turns out that the waste problem in Indonesia is becoming more complex and widespread, especially related to the issue of marine waste pollution. The results of Jambeck's research, Jena R, et al, (2015) state that the potential for plastic waste in Indonesia's oceans reaches 187.2 million tons / year. With the results of this study, Indonesia is the second largest country that contributes waste after China, followed by the Philippines, Vietnam and Sri Lanka. According to Greenation Research, a non-governmental organization that has been following the issue of solid waste for 10 years, one Indonesian produces 700 plastic bags per year (Kementerian Pekerjaan Umum dan Perumahan Rakyat, 2016).

Sources of waste generation can come from a variety of places, such as households, offices, trade, industry, construction waste, roads, fisheries / livestock and mining. And the waste generated varies based on where it was generated. For waste handling that has been commonly carried out is direct disposal to the final dumping site (TPA) by open dumping.

Campus 7 Health Polytechnic of the Ministry of Health Semarang, is an educational institution that is integrated with a canteen, housing for lecturers and has open land which reaches 2.3 ha, where organic waste is generated on average $4 \mathrm{~m} 3$ / week and inorganic waste averages $0.85 \mathrm{~m} 3$ / week with plastic predominance (GELISH, 2019). To overcome the accumulation of waste, it is necessary to optimize waste processing. Dispose of waste in the usual way by simply throwing the waste in a temporary shelter (TPS) which is then disposed of in final disposal (TPA). This is still considered ineffective in overcoming the existing problems, by taking into account the regent's circular number: 660.1 / $7776 / 2018$, in the circular letter the regent explicitly instructs the closure of the existing landfill starting January 2, 2019 and urges waste management through Community Self-Help Groups KSM) in 3R waste management. Campus 7 as an educational institution in which there is a Department of Environmental Health and has qualified human resources (HR) in the field of waste processing has pioneered a composter pilot unit with the run way method which is arranged in 10 basins. Efforts to handle organic waste have been realized in the form of processing products in the form of organic compost. Along with composting activities, activity evaluation activities are carried out. The results of the evaluation are important notes in the composting process. Campus 7 as an educational institution in which there is a Department of Environmental Health and has qualified human resources (HR) in the field of waste processing has pioneered a composter pilot unit with the run way method which is arranged in 10 basins. Efforts to handle organic waste have been realized in the form of processing products in the form of organic compost. Along with composting activities, activity evaluation activities are carried out. The results of the evaluation show important notes on the composting process carried out, such as the process of turning over too much waste, transferring waste to many composting basins, complaints of pungent odors and the risk of being punctured from can / glass waste. All of these conditions were caused by activities being carried out manually by cleaning personnel.

\section{Material and Method}

Research and Development is a research method that uses to obtain or develop products and test the effectiveness of these products. With the design of tools for comparing the results before and after using the tools used. This research was conducted at a waste processing site (composter) at Campus 7 Poltekkes Kemenkes Semarang. The population in this study is all of the waste generation from campus 7 residents The sample of this study is the waste found in the final (10th) compost container, about a volume of $0.5-1 \mathrm{~m} 3$ / week. The data analysis used in this research is table analysis and the average value calculated from the results of sieving the waste.

\section{Result and Discussion}

A. Result

1) Assembly Tool

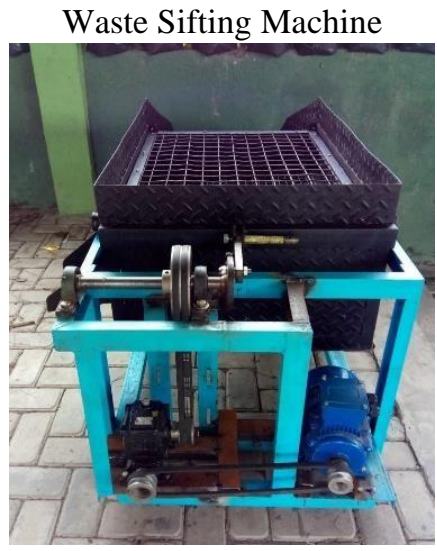

2) Manual Sifting

Number of personnel : 3 people

Time which Required: 9:45 am-11:00 am

(75 minute) 
a. Weighing trash

Amount of trash

- results of the compost process: 531.2 liters $(238.5 \mathrm{~kg})$

- $176 \mathrm{lt}(43.5 \mathrm{~kg})$ of sorted plastic waste

- The amount of waste to be sieved is 355.2 lt $(195 \mathrm{~kg})$

b. Equipment used: broom stick, shovel, trash bin, scale, sieve by the size $5 \mathrm{~cm}$ and sieve bythe size $1 \mathrm{~cm}$.

c. Results of manual sifting

\begin{tabular}{|c|l|c|c|c|}
\hline $\begin{array}{c}\mathbf{N} \\
\mathbf{o}\end{array}$ & $\begin{array}{l}\text { Litter } \\
\text { size }\end{array}$ & $\begin{array}{c}\text { Mass } \\
(\mathbf{K g})\end{array}$ & $\begin{array}{c}\text { Volume } \\
(\mathbf{L t})\end{array}$ & $\mathbf{\%}$ \\
\hline 1 & $\begin{array}{l}\text { Manual } \\
\text { sorting } \\
\text { results }\end{array}$ & 79,02 & 176 & $\begin{array}{c}33,13 \\
253\end{array}$ \\
\hline 2 & $>=5 \mathrm{~cm}$ & 32,33 & 72 & $\begin{array}{c}13,55 \\
422\end{array}$ \\
\hline 3 & $\begin{array}{c}<5 \mathrm{~cm} \mathrm{s.d} \\
1 \mathrm{~cm}\end{array}$ & 42,38 & 94,4 & $\begin{array}{c}17,77 \\
108\end{array}$ \\
\hline 4 & $<1 \mathrm{~cm}$ & 84,77 & 188,8 & $\begin{array}{c}35,54 \\
217\end{array}$ \\
\hline \multicolumn{2}{|c|}{ Total } & 238,50 & 531,20 & 100 \\
\hline
\end{tabular}

Manual Sifting Process

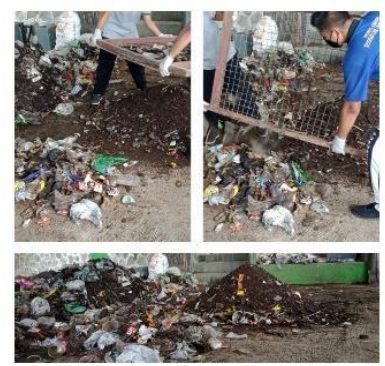

Manual Sifting Process
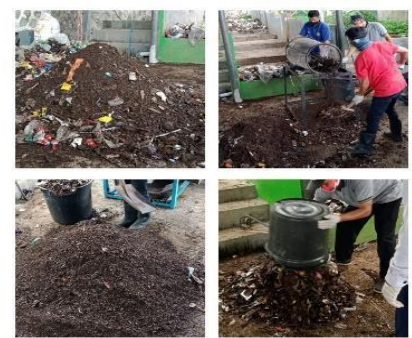

Machine Sifting

Number of personnel

: 2 people

Time Required

: $13.25-13.48(23$ a. Weighing trash

Amount of trash

- results of the compost process: 531.2 liters $(238.5 \mathrm{~kg})$

- 176 lt (43.5 kg) of sorted plastic waste

- The amount of waste to be sieved is 355.2 lt (195 kg)

b. Equipment used: shovel, measuring box trash, scales, sieve machines

3) Results of manual sifting

\begin{tabular}{|c|c|c|c|c|}
\hline No & $\begin{array}{l}\text { Litter } \\
\text { size }\end{array}$ & $\begin{array}{r}\text { Mass } \\
(\mathrm{Kg})\end{array}$ & $\begin{array}{c}\text { volume } \\
\text { (Lt) }\end{array}$ & $\%$ \\
\hline 1 & $\begin{array}{l}\text { Manual } \\
\text { sorting } \\
\text { results }\end{array}$ & 79,02 & 176 & 33,13 \\
\hline 2 & $>=5 \mathrm{~cm}$ & 33,05 & 73,6 & 13,86 \\
\hline 3 & $\begin{array}{l}<5 \mathrm{~cm} \\
\text { s.d }>=2 \mathrm{~cm}\end{array}$ & 27,39 & 61 & 11,48 \\
\hline 4 & $\begin{array}{l}<2 \mathrm{~cm} \\
\text { s.d }>=1 \mathrm{~cm}\end{array}$ & 15,71 & 35 & 6,59 \\
\hline 5 & $<1 \mathrm{~cm}$ & 83,33 & 185,6 & 34,94 \\
\hline \multicolumn{2}{|c|}{ Jumlah } & 238,50 & 531,2 & 100 \\
\hline
\end{tabular}

Machine Sifting

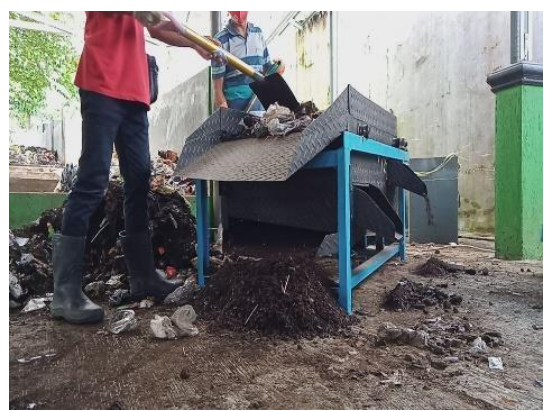

Machine Sifting

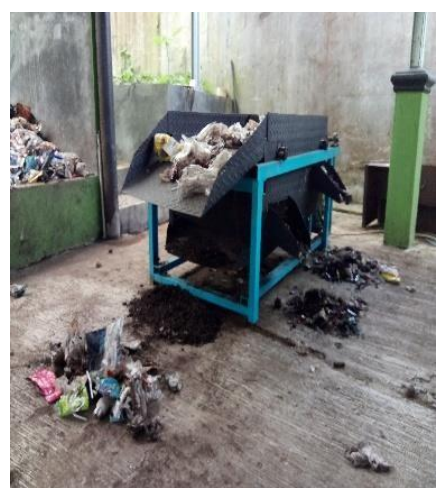

minute) 
Tools Spesification

\begin{tabular}{|l|l|l|}
\hline $\begin{array}{l}\text { Volume } \\
\text { of Tool }\end{array}$ & $:$ & $\begin{array}{l}100 \times 70 \times 70 \\
\mathrm{~cm}\end{array}$ \\
\hline $\begin{array}{l}\text { Weigh } \\
\text { ofTool }\end{array}$ & $:$ & $110 \mathrm{Kg}$ \\
\hline $\begin{array}{l}\text { Power of } \\
\text { AC }\end{array}$ & $:$ & $380 \mathrm{~V} / 3 \mathrm{HP}$ \\
\hline
\end{tabular}

\begin{tabular}{|l|l|l|}
\hline $\begin{array}{l}\text { Drive } \\
\text { motor } \\
\text { capacity }\end{array}$ & $:$ & $1425 \mathrm{rpm}$ \\
\hline $\begin{array}{l}\text { Sieve } \\
\text { moveme } \\
\text { nt (back } \\
\text { and } \\
\text { forth) }\end{array}$ & $:$ & $\begin{array}{l}120 \\
\text { times/minutes }\end{array}$ \\
\hline $\begin{array}{l}\text { Sieve } \\
\text { size }\end{array}$ & $:$ & $\begin{array}{l}\text { Stage } 1: 5 \mathrm{~cm}, \\
\text { Stage } 2: 2 \mathrm{~cm} \\
\text { and stage } 3: 1 \\
\text { cm }\end{array}$ \\
\hline $\begin{array}{l}\text { Workl } \\
\text { oad }\end{array}$ & $: \begin{array}{l}15,44 \\
1 \mathrm{t} / \text { minutes } \\
(8,5 \\
\text { kg/minutes }) \\
=926,4 \text { lt/hour } \\
(510 \text { kg/jam })\end{array}$ \\
\hline
\end{tabular}

4) Advantages of the tool

a) Waste sieving machine is capable of separating waste compost into 4 parts quickly

b) The compost sieving machine is equipped with a work safety in the sieving section.

5) Lack of tools in the first function test

a) Waste is not smooth in the second sieve (size $2 \mathrm{~cm}$ ), because the waste from the first sieve with a size of $5 \mathrm{~cm}$ can quickly get out into the second sieve.

b) The rest of the waste in the 2nd and 3rd sieve still does not come out smoothly

c) Waste compost entry technique which is still manual.

\section{B. Discussion}

The compost sieving machine takes about 3 months from design to assembly. Furthermore, the first tool function test is carried out for about a month.
The results of the first function test showed that there was a buildup of waste in the second stage (size $2 \mathrm{~cm}$ ) this happens because the waste from the sieve stage 1 (size $5 \mathrm{~cm}$ ) easily comes out to the second sieve stage. the second shortcoming is the non-smooth discharge of the remaining waste in the $2 \mathrm{nd}$ and $3 \mathrm{rd}$ sieves.

In the second function test of the waste compost is running smoothly as planned with the cost of weighing capacity of 1544 / minute $(8.5 \mathrm{~kg} /$ minute). Then the sifter was able to sift through the litter of $926.4 \mathrm{lt} / \mathrm{hr}(510 \mathrm{~kg} / \mathrm{h})$. So it was able to complete the garbage compost sifter on campus 7 . The sifting results are follows:

- The size of plastic waste $>=5 \mathrm{~cm}$ is carried out by further processes such as cleaning, enumerating and smelting (whose tools have been completed in the 2019 research)

- Compost size $\langle 5 \mathrm{~cm} \mathrm{~s}, \mathrm{~d}\rangle=2 \mathrm{~cm}$ is put back in the compost process from the first stage again.

- Compost size $\langle 2 \mathrm{~cm}$ to $\rangle=1 \mathrm{~cm}$ is chopped and re-sieved

- Compost $<1 \mathrm{~cm}$ size can be directly or mixed with cow / goat manure to be used as compost.

As for the weaknesses, it can be done some way:

- add a sifter from 200 to 300 , so that the waste will be faster down through the sieve.

- put a 450 slant which leads to the spending hole on sifter 2 and stage 3 , so the rest of the sifter litter should be pointed out.

From the observations of the work of the tool, there are several work steps for the operation of the tool:

- Sorting out large plastic and other waste

- Prepare the machine ready for operation.

- Incorporate waste compost gradually.

- If the sieving machine jams, turn off the power and check the sieve at each stage.

\section{Conclusion}

The waste compost sieving machine can meet the needs in supporting the waste processing process on campus 7, especially in sorting compost. Sieving capacity $15.44 \mathrm{lt} /$ minute $(8.5 \mathrm{~kg} /$ minute). So the sieving machine is able to sieve $926.4 \mathrm{lt} /$ hour (510 $\mathrm{kg} /$ hour) of compost. So that it can complete the compost sieving on campus 7 as much as $355.2 \operatorname{lt}$ (195 $\mathrm{kg}$ ) per week in 23 minutes.

\section{Acknowledgment}

Many thanks are conveyed to Poltekkes Kemenkes Semarang 


\section{Reference}

Alex S. 2012. Sukses Mengolah Sampah Organik Menjadi Pupuk Organik. Yogyakarta: Pustaka Baru Press.

Chandra, Budiman (2006) Pengantar Kesehatan Lingkungan. EGC. Jakarta

Enri Damanhuri dan Tri Padmi. 2010. Diktat Pengelolaan Sampah. ITB: Bandung.

GELISH, 2018. Pengolahan Sampah menjadi Kompos. Jurusan Kesehatan Lingkungan

Jenna R.Jambeck, Roland Geyer, Chris Wilcox, Theodore R.Sieger, Miriam Perryman, Anthony Andrady, Ramani Narayan, Kara Lavender Law. 2015. Plastic waste inputs from land into the ocean. Sciencemag 13 February 2015 Vol 374 Issue 6223.

Manik, K.E.S., 2003. Pengelolaan Lingkungan Hidup. Djambatan. Jakarta.

Mutharjo, Djuli dan Said, E. G. 1997. Penanganan dan Pemanfaatan Limbah Padat. Jakarta: Madyatma Saran Perkasa.

Notoatmodjo, Soekidjo, 2003. Ilmu Kesehatan Masyarakat. Rineka Cipta, Jakarta

Nugroho Panji, 2013. Panduan Membuat Kompos Cair. Jakarta: Pustaka baru Press
Peraturan Pemerintah Republik Indonesia, nomor 17 Tahun 2010, tentang Pengelolaan dan Penyelenggaraan Pendidikan. Jakarta.

Siti Marwati. 2013. Pengelolaan Sampah Mandiri Berbasis Masyarakat. Jurusan Pendidikan Kimia FMIPA UNY.

Slamet, J. S. 1994. Kesehatan Lingkungan. Yogyakarta: Gadjah Mada Universsity Press.

Slamet Santoso SP. 2010. Dampak Negatif Sampah Terhadap Lingkungan dan Upaya Mengatasinya. Fakultas Biologi UNSOED.

Suprihatin, Agung Dwi Prihanto dan Michel Gelbert. 1996 Sampah dan Pengelolaannya. Malang: PPPGT

Tobing, I. S. (2005). Dampak Sampah Terhadap Kesehatan Lingkungan dan Manusia. Jakarta: Fakultas Biologi Universitas Nasional, 1-9.

Undang-Undang Nomor 18 Tahun 2008 Tentang Pengelolaan Sampah.

Widyatmoko, H dan Sitorini. 2002. Menghindari, Mengolah, dan Menyingkirkan Sampah. Jakarta: Abdi Tandur. 